\title{
PENGARUH PEMBERIAN REBUSAN DAUN BINAHONG (ANREDERA CORDIFOLIA) TERHADAP KADAR GLUKOSA DARAH PADA WANITA DEWASA
}

\author{
Sudirman $^{1}$, Aryu Candra Kusumastuti ${ }^{1}$ \\ ${ }^{1}$ Departemen Ilmu Gizi, Fakultas Kedokteran, Universitas Diponegoro \\ Jln. Prof. H. Soedarto, SH., Semarang, Telp (024) 76402881, Email : gizifk@ undip.ac.id
}

\begin{abstract}
Background:Diabetes Mellitus (DM) is a metabolic disease that occur due to the damage on insulin secretion and insulin work, which can be measured by looking at blood glucose levels. Binahong leaves is containing saponins has the same activity like insulin, including lipolysis inhibit, and increase glucose uptake by the adipose cells. This study aim is to analyze difference changes on blood glucose levels of adult women.

Methods:This study is a quasi-experimentwith design control group pre test-post test of 22 adults women in PGRI housing, disnakertrans office, and kesbangpol office semarang city aged 34-53 years in june 2016. The treatment group was given boiled leaves of binahong as much as $155 \mathrm{~g} / 70 \mathrm{kgBB}$ while the control group was given $2 \mathrm{~g}$ sugar and 0 calories by adding water $250 \mathrm{ml}$. interventions carried out for 14 days. T-test method was used to analyze the different test of decoction of binahong leaves on fasting blood glucose before and after intervention.

Results:There was a significant difference of GDP levels in both of groups ( $p<0.05$ ), where GDP levels89.64 $\pm 9.45 \mathrm{mg} / \mathrm{dl}$ in the treatment group and $98.54 \pm 15.00 \mathrm{mg} / \mathrm{dl}$ in the control group. Decrease GDP levels in the treatment group $(99.45$ $\pm 10.80 \mathrm{mg} / \mathrm{dl})$ into $(89.64 \pm 9.45 \mathrm{mg} / \mathrm{dl})$. The increase in GDP levels occurred in the control group $(95.64 \pm 13.50 \mathrm{mg} / \mathrm{dl})$ into $(98.54 \pm 15.00 \mathrm{mg} / \mathrm{dl})$.
\end{abstract}

Conclusion: A decoction of binahong leaves can decrease GDP levels in adults women.

Keywords: Binahong leaves of decoction, fasting glucose, adult women, saponin

\begin{abstract}
ABSTRAK
Latar belakang :Diabetes Melitus (DM) merupakan suatu penyakit metabolik yang terjadi akibat kerusakan pada sekresi insulin dan kerja insulin yang dapat diukur dengan melihat kadar glukosa dalam darah. Daun binahong memiliki kandungan saponin yang mempunyai aktivitas seperti insulin, dapat menghambat lipolisis, dan meningkatkan pengambilan glukosa oleh sel adipose. Penelitian ini bertujuan untuk menganalisis perbedaan perubahan kadar glukosa darah pada wanita dewasa.

Metode:Penelitian ini merupakan penelitian quasi-experiment dengan rancangan control group pre test-post test pada 22 wanita dewasa di perumahan PGRI, kantor disnakertrans dan kantor kesbangpol kota semarang usia 34-53 tahun pada bulan juni 2016. Kelompok perlakuan diberikan rebusan daun binahong sebanyak 155 g/70 kgBB sedangkan kelompok control diberikan $2 \mathrm{~g}$ gula 0 kalori dengan penambahan air sebanyak $250 \mathrm{ml}$. Intervensi dilakukan selama 14 hari. Metode t-test digunakan untuk menganalisis uji beda pengaruh rebusan daun binahong terhadap kadar gula darah puasa sebelum dan sesudah intervensi.

Hasil:Terdapat perbedaan signifikan kadar GDP antara kedua kelompok ( $p<0.05$ ), dimana kadar GDP 89.64 \pm 9.45 mg/dl pada kelompok perlakuan dan $98.54 \pm 15.00 \mathrm{mg} / \mathrm{dl}$ pada kelompok kontrol. Terjadi penurunan kadar GDP pada kelompok perlakuan $(99.45 \pm 10.80 \mathrm{mg} / \mathrm{dl})$ menjadi $(89.64 \pm 9.45 \mathrm{mg} / \mathrm{dl})$. Peningkatan kadar GDP terjadi pada kelompok kontrol $(95.64 \pm 13.50 \mathrm{mg} / \mathrm{dl})$ menjadi $(98.54 \pm 15.00 \mathrm{mg} / \mathrm{dl})$.
\end{abstract}

Kesimpulan :Pemberian rebusan daun binahong dapat menurunkan kadar gula darah puasa pada wanita dewasa.

Kata Kunci:Rebusan daun binahong, gula darah puasa, wanita dewasa, saponin

\section{PENDAHULUAN}

Diabetes melitus (DM) merupakan suatu penyakit metabolik yang terjadi akibat kerusakan pada sekresi insulin dan kerja insulin yang dapat ditandai dengan hiperglikemia. ${ }^{1}$ Berdasarkan etiologi terdapat 2 jenis DM, yaitu DM tipe 1 dan DM tipe 2. DM tipe 1 atau Insulin Dependent Diabetes Mellitus (IDDM) disebabkan oleh penyakit autoimun. Kerusakan autoimun dapat menyebabkan sel $\beta$ yang terletak dipulau langerhans pada pankreas tidak dapat mensekresi kembali insulin. Sedangkan DM tipe 2 atau Non Insulin Dependent Diabetes Mellitus (NIDDM) merupakan DM yang disebabkan oleh resistensi insulin dan biasanya hanya relatif (bukan absolut) terjadi defisiensi insulin pada awalnya. ${ }^{2,3}$

Menurut World Health Organization (WHO) September 2012 bahwa penderita DM didunia mencapai 347 juta jiwa dan $80 \%$ lebih berasal dari negara miskin dan negara berkembang seperti indonesia. ${ }^{4}$ Sedangkan di indonesia menurut Departemen Kesehatan memperkirakan tahun 2030 penderita DM sebanyak 21,3 juta jiwa. Sebanyak 1,3 
juta jiwa meninggal disebabkan oleh DM.4,5 Berdasarkan hasil riskesdas 2013 menunjukkan prevalensi DM di indonesia berdasarkan diagnosis atau gejala sebesar 2,1\% dan prevalensi DM tertinggi yaitu pada usia 55 sampai 65 tahun sebesar $4,8 \%{ }^{6}$

Suatu penelitian menunjukkan bahwa DM merupakan salah satu faktor risiko penyakit jantung koroner. ${ }^{7}$ Penelitian lain menyebutkan bahwa wanita dengan DM tipe 2 lebih berisiko 5 - 7 kali memiliki kematian yang lebih tinggi melalui penyempitan pembuluh darah jantung. ${ }^{8}$ Besarnya insidensi, prevalensi, dan komplikasi DM menggambarkan betapa pentingnya pencegahan dan penatalaksanaan penyakit tersebut. Manajemen DM sangat efektif dilakukan pada tahap awal sebelum timbul gejala atau prediabetes. ${ }^{9}$ Prediabetes ditandai dengan kadar glukosa darah puasa antara $100-125 \mathrm{mg} / \mathrm{dL} .{ }^{10}$

Faktor-faktor risiko prediabetes diantara lain : Riwayat keluarga dengan diabetes, aktifitas fisik, usia, jenis kelamin, penyakit penyerta, konsumsi alkohol, indeks massa tubuh, kebiasaan merokok, konsumsi obat-obatan, dan asupan makanan. ${ }^{10-15}$

Faktor makanan merupakan poin utama yang memiliki efek yang signifikan dalam menurunkan kadar glukosa darah. Salah satu tanaman yang dihubungkan dengan perbaikan kondisi prediabetes melalui penurunan kadar glukosa darah adalah binahong. Tanaman binahong atau yang biasa disebut (Anredera cordifolia) merupakan tanaman merambat yang mudah tumbuh di indonesia, mempunyai ciriciri yaitu memiliki batang kecil, memiliki rizhoma yang kuat dan memiliki daun yang tidak begitu besar. ${ }^{16}$ Daun binahong lebih efektif dibandingkan batang dan akar untuk dijadikan sebagai bahan utama dalam menurunkan kadar glukosa karena dapat diperoleh dalam jumlah yang banyak dan tidak mempengaruhi kehidupan dari tanaman tersebut. Daun binahong memiliki kandungan saponins, alkaloids, polyphenols, flavonoid dan mono polysaccharide. Dari 20 g sampel daun binahong memiliki total saponin triterpenoid dan steroid sekitar ( $28.14 \pm 0,22$ ). ${ }^{17}$ Triterpenoid merupakan jenis senyawa yang dapat larut air sedangkan senyawa steroid larut dalam lemak. ${ }^{18}$

Senyawa saponin dapat menurunkan kadar glukosa darah. Saponin merupakan suatu glikosida alamiah yang terikat dengan steroid atau triterpena. Saponin mempunyai aktivitas seperti insulin, dapat menghambat lipolisis, meningkatkan pengambilan glukosa oleh sel adipose. Sebuah penelitian menunjukkan bahwa senyawa saponin dapat memperbaiki resistensi insulin. ${ }^{19}$ Senyawa saponin juga tahan terhadap pemanasan sehingga tidak akan rusak apabila dilakukan perebusan terhadap daun binahong. ${ }^{20}$
Kelarutan senyawa saponin pada air dengan suhu $30^{\circ} \mathrm{C}$ sebanyak $7,4 \mathrm{~g} / 100 \mathrm{~mL}$ dan akan meningkat pada suhu $70^{\circ} \mathrm{C}$ sebanyak $18,0 \mathrm{~g} / 100$ $\mathrm{mL}^{21}$ Penelitian lain juga membuktikan bahwa terjadi peningkatan bioavaibilitas saponin pada minuman yang direbus dengan suhu $70^{\circ} \mathrm{C}$ sampai $100^{\circ} \mathrm{C}$ dengan lama pencelupan 1 sampai 7 menit yang dilakukan dengan daun kumis kucing. Hasilnya, minuman yang mempunyai karakteristik fisikokimia terbaik adalah minuman yang direbus dengan suhu $80^{\circ} \mathrm{C}$ selama 3 menit. $^{22}$

Hasil uji coba yang dilakukan untuk mencapai suhu sampai $80^{\circ} \mathrm{C}$ dapat ditempuh menggunakan waktu selama \pm 4 menit dengan menggunakan api sedang. Ciri-ciri dari hasil perebusan yaitu sebelum air mendidih namun sudah mengeluarkan uap, dengan tujuan agar senyawa aktif lainnya tidak rusak dengan adanya pemanasan suhu yang terlalu tinggi. Perebusan daun binahong dilakukan dengan tujuan untuk mengurangi kandungan getah dan rasa pahit pada daun binahong serta membuat warna daun lebih cerah sehingga lebih diminati masyarakat. Penelitian ini dilakukan dengan memberikan rebusan daun binahong sebanyak 155 g/70 kgBB dengan lama waktu pemberian selama 14 hari pada manusia.

Penelitian tentang pengaruh konsumsi daun binahong terhadap penurunan kadar glukosa darah pada manusia belum pernah dilakukan. Penelitian pada mencit yang diberikan ekstrak daun binahong secara oral sebanyak 50, 100 dan $200 \mathrm{mg} / \mathrm{kgBB}$ yang dilakukan selama 14 hari menunjukkan bahwa ekstrak daun binahong dapat menurunkan kadar glukosa darah dalam pemantauan kadar glukosa yang dilakukan pada hari ke 1, 7 dan $14 .{ }^{23}$ Penelitian lain pada tikus wistar yang diberikan ekstrak daun binahong dengan dosis $1,8 \mathrm{~g} / \mathrm{kgBB}$ juga menunjukkan penurunan kadar glukosa darah pada tikus wistar. ${ }^{24}$ Dari beberapa jenis dosis ekstrak daun binahong yang diberikan pada tikus wistar tidak memberikan beda yang signifikan dalam penurunan kadar glukosa darah.

\section{METODE}

Penelitian ini dilakukan di perumahan PGRI, kantor Disnakertrans dan kantor Kesbangpol kota Semarang pada bulan juni 2016. Penelitian ini merupakan penelitian quasi-experiment dengan rancangan control group pre test - post test. dan termasuk dalam ruang lingkup gizi klinik. Subjek penelitian adalah wanita dengan usia $\geq 35$ tahun dan belum menopause dengan kriteria inklusi tidak sedang mengonsumsi obat-obatan antihiperglikemik selama penelitian, tidak dalam keadaan sakit atau dalam perawatan dokter berkaitan dengan penyakit jantung koroner, diabetes mellitus, hipertensi, gagal 
ginjal, dan penyakit kronik lainnya, dan bersedia menjadi subjek penelitian dengan mengisi informed consent dari awal penelitian hingga akhir.

Penelitian ini dibagi menjadi dua kelompok yaitu kelompok perlakuan dan kontrol. Pembagian kelompok dilakukan dengan cara acak (random) dimana setiap subjek yang memenuhi kriteria inklusi memiliki kesempatan yang sama untuk masuk dalam kelompok perlakuan maupun kontrol. Masingmasing kelompok diperlukan 10 orang dengan penambahan faktor drop out sebesar $10 \%$ menjadi 11 orang. Jumlah sampel ditentukan dengan menggunakan rumus uji hipotesis terhadap rerata dua populasi independen (lampiran. 2).

Variabel bebas pada penelitian ini yaitu pemberian rebusan daun binahong. Daun binahong lebih efektif dibandingkan batang dan akar untuk dijadikan sebagai bahan utama dalam menurunkan kadar glukosa karena dapat diperoleh dalam jumlah yang banyak dan tidak mempengaruhi kehidupan dari tanaman tersebut. Sedangkan perebusan daun binahong dilakukan dengan tujuan untuk mengurangi kandungan getah dan rasa pahit pada daun binahong serta membuat warna daun lebih cerah sehingga lebih diminati masyarakat.

Kelompok perlakuan diberikan rebusan daun binahong sebanyak $155 \mathrm{~g} / 70 \mathrm{kgBB}$. Jumlah tersebut didapatkan berdasarkan penelitian sebelumnya yang menggunakan ekstrak daun binahong yang kemudian dikalkulasikan melalui hasil perhitungan (lampiran. 3). Daun binahong didapat dari pembudidayaan tanaman binahong kabupaten cianjur Jawa Barat. Daun binahong dicincang menggunakan pisau sebelum ditimbang dengan menggunakan timbangan $X$ dengan skala $0,01 \mathrm{mg}$ sesuai dengan hitungan berat badan subjek dengan penambahan air sebanyak \pm 140 $\mathrm{ml}$ dan kemudian dilakukan perebusan hingga $80{ }^{\circ} \mathrm{C}$ atau selama \pm 4 menit. Selanjutnya didinginkan dan ditempatkan pada kemasan polyetilen dengan ukuran 16. Waktu perebusan serta suhu disesuaikan berdasarkan penelitian sebelumnya yang membahas tentang bioavaibilitas terhadap saponin yang merupakan senyawa utama dalam mempengaruhi kadar gula darah dalamtubuh. ${ }^{21,22}$

Pemberian intervensi dilakukan selama 14 hari dan pengambilan data recall dilakukan sebanak 3 kali yaitu sebelum intervensi, pada saat intervensi, dan setelah intervensi. Semua subjek dipastikan untuk menghabiskan intervensi yang diberikan. Sedangkan kelompok kontrol diberikan 2 g gula 0 kalori dengan penambahan air sebanyak $250 \mathrm{ml}$ yang dikemas dalam wadah dengan ukuran yang sama.

Variabel terikat adalah kadar glukosa darah puasa yang diambil oleh petugas laboratorium melalui pembuluh vena di lengan yang dapat diukur setelah subjek berpuasa selama \pm 10 jam. Pengukuran glukosa darah dilakukan dua kali yaitu satu hari sebelum dan hari ke-empat belas intervensi. Beberapa variabel seperti asupan karbohidrat, lemak, protein, vitamin, serat dan aktivitas fisik menjadi variabel perancu yang akan dikendalikan melalui analisis.

Data yang dikumpulkan meliputi data identitas subjek (nama, usia, tanggal lahir), dan aktivitas fisik, yang diperoleh dengan menggunakan kuesioner. Pengambilan data ini dilakukan satu hari sebelum intervensi yaitu sebelum pengukuran glukosa darah puasa awal.

Pengukuran tinggi badan dilakukan dengan menggunakan mikrotoa dengan batas ukur $200 \mathrm{~cm}$ dan ketelitian $0,1 \mathrm{~cm}$. Pengukuran berat badan diperoleh melalui penimbangan menggunakan BEA dengan skala $0,1 \mathrm{~kg}$. Data asupan makan masingmasing kelompok diambil sebanyak tiga kali pada saat sebelum, saat, dan setelah intervensi dengan metode recall 24 jam untuk mengetahui data asupan karbohidrat, protein, lemak, vitamin, dan serat. Mengacu pada penelitian Baecke JA, dkk data aktivitas fisik diukur berdasarkan intensitas, durasi, dan frekuensi olahraga yang dilakukan dengan menggunakan kuesioner Measurement of Habitual Physical Acitivity dimana masing-masing nilai intensitas, durasi dan frekuensi akan dikalikan sehingga mendapatkan hasil akhir berupa skor (lampiran. 4). Intensitas akan dibagi menjadi tiga kategori ringan, moderat, dan berat yang memiliki nilai berbeda yaitu $<5.6$ untuk intensitas ringan, 5.6 7.9 untuk intensitas moderat, dan $>7.9$ untuk intensitas berat. ${ }^{25}$

\section{HASIL PENELITIAN \\ Karakteristik subjek}

Penelitian dilakukan di perumahan PGRI, kantor Disnakertrans dan kantor Kesbangpol kota Semarang. Subjek penelitian adalah 22 wanita dewasa dengan rata-rata usia $\geq 35$ tahun dan belum menopause.

Menurut Kemenkes 2013, kategori IMT dibagi menjadi 4 yaitu kurus $(<18.5)$, normal $(\geq 18.5$ $<24.9)$, berat badan lebih $(\geq 25-<27)$, dan obesitas $(\geq 27) .{ }^{26}$ Variabel GDP menurut Ahmad Rudianto, dkk menjelaskan bahwa kadar gula darah puasa dikatakan rendah apabila $(<80)$, normal (80-100), dan prediabetes (100-125). ${ }^{10}$ Sedangkan pada variabel asupan zat gizi mengacu pada angka kecukupan gizi Indonesia. ${ }^{27}$ Menurut Gibson RS, seseorang dikatakan memenuhi kecukupan zat gizi apabila asupan zat gizinya mencapai $77 \%$ dari kebutuhan sehari-hari. ${ }^{28}$ Sehingga variabel asupan zat gizi dapat dikategorikan menjadi 2 yaitu kategori kurang dan cukup. 
Tabel 1. Karakteristik subjek penelitian pada kedua kelompok sebelum intervensi.

\begin{tabular}{|c|c|c|}
\hline \multirow{2}{*}{ Gambaran subjek/kategori } & \multicolumn{2}{|c|}{ Perlakuan dan kontrol } \\
\hline & Jumlah responden & Persentase (\%) \\
\hline \multicolumn{3}{|l|}{$\operatorname{IMT}\left(\mathrm{kg} / \mathrm{m}^{2}\right)$} \\
\hline Kurus & 1 & 4.54 \\
\hline Normal & 4 & 18.18 \\
\hline Berat badan lebih & 4 & 18.18 \\
\hline Obesitas & 13 & 59.09 \\
\hline \multicolumn{3}{|l|}{ GDP (mg/dl) } \\
\hline Rendah & 0 & 0 \\
\hline Normal & 16 & 72.73 \\
\hline prediabetes & 6 & 27.27 \\
\hline \multicolumn{3}{|l|}{ Karbohidrat (g) } \\
\hline Kurang & 22 & 100 \\
\hline Cukup & 0 & 0 \\
\hline \multicolumn{3}{|l|}{ Protein $(g)$} \\
\hline Kurang & 19 & 86.37 \\
\hline Cukup & 3 & 13.63 \\
\hline \multicolumn{3}{|l|}{ Lemak (g) } \\
\hline Kurang & 19 & 86.37 \\
\hline Cukup & 3 & 13.63 \\
\hline \multicolumn{3}{|l|}{ Serat $(g)$} \\
\hline Kurang & 22 & 100 \\
\hline Cukup & 0 & 0 \\
\hline \multicolumn{3}{|l|}{ Vit. A $(\mu \mathrm{g})$} \\
\hline Kurang & 4 & 18.18 \\
\hline Cukup & 18 & 81.82 \\
\hline \multicolumn{3}{|l|}{ Vit. B1 (mg) } \\
\hline Kurang & 22 & 100 \\
\hline Cukup & 0 & 0 \\
\hline \multicolumn{3}{|l|}{ Vit. B2 (mg) } \\
\hline Kurang & 22 & 100 \\
\hline Cukup & 0 & 0 \\
\hline \multicolumn{3}{|l|}{ Vit. B6 (mg) } \\
\hline Kurang & 20 & 90.91 \\
\hline Cukup & 2 & 9.09 \\
\hline \multicolumn{3}{|l|}{ Vit. C (mg) } \\
\hline Kurang & 19 & 86.37 \\
\hline Cukup & 3 & 13.63 \\
\hline \multicolumn{3}{|l|}{ Vit. D $(\mu \mathrm{g})$} \\
\hline Kurang & 22 & 100 \\
\hline Cukup & 0 & 0 \\
\hline
\end{tabular}

Tabel 2. Rata-rata usia, IMT, GDP, dan asupan zat gizi pada kedua kelompok sebelum intervensi.

\begin{tabular}{|c|c|c|c|c|c|c|c|}
\hline \multirow{2}{*}{$\begin{array}{c}\text { Gambaran } \\
\text { subjek }\end{array}$} & \multicolumn{3}{|c|}{ Perlakuan $(\mathrm{n}=11)$} & \multicolumn{3}{|c|}{ Kontrol (n=11) } & \multirow[b]{2}{*}{$p$} \\
\hline & Mean \pm SD & Min & Max & Mean \pm SD & Min & Max & \\
\hline Usia (th) & $46.64 \pm 4.48$ & 39 & 53 & $44.91 \pm 5.39$ & 34 & 52 & $0.42 * *$ \\
\hline $\operatorname{IMT}\left(\mathrm{kg} / \mathrm{m}^{2}\right)$ & $26.92 \pm 4.10$ & 17.68 & 32.59 & $27.57 \pm 4.51$ & 19.50 & 32.98 & $0.72 * *$ \\
\hline $\mathrm{GDP}(\mathrm{mg} / \mathrm{dl})$ & $99.45 \pm 10.80$ & 84.00 & 117.00 & $95.64 \pm 13.50$ & 82.00 & 131.00 & $0.32 *$ \\
\hline $\mathrm{KH}(\mathrm{g})$ & $115.03 \pm 28.06$ & 62.93 & 149.37 & $141.06 \pm 48.26$ & 82.33 & 223.67 & $0.14 * *$ \\
\hline Protein $(\mathrm{g})$ & $28.99 \pm 11.09$ & 18.97 & 57.73 & $31.85 \pm 18.90$ & 15.00 & 68.33 & $0.87 *$ \\
\hline Lemak (g) & $31.21 \pm 13.07$ & 17.27 & 62.17 & $25.45 \pm 12.41$ & 13.67 & 50.67 & $0.18 *$ \\
\hline Serat $(\mathrm{g})$ & $6.31 \pm 1.64$ & 3.40 & 9.07 & $5.70 \pm 3.65$ & 2.33 & 15.00 & $0.18 *$ \\
\hline Vit. A $(\mu \mathrm{g})$ & $632.36 \pm 301.31$ & 299.73 & 1330.87 & $614.27 \pm 299.55$ & 214.67 & 1267.67 & $0.89 * *$ \\
\hline Vit.B1(mg) & $0.29 \pm 0.06$ & 0.20 & 0.37 & $0.34 \pm 0.19$ & 0.13 & 0.80 & $0.84 *$ \\
\hline Vit.B2(mg) & $0.34 \pm 0.12$ & 0.13 & 0.60 & $0.38 \pm 0.23$ & 0.17 & 0.93 & $0.92 *$ \\
\hline Vit.B6(mg) & $0.62 \pm 0.17$ & 0.37 & 0.87 & $0.66 \pm 0.41$ & 0.30 & 1.70 & $0.45 *$ \\
\hline Vit. C (mg) & $42.53 \pm 20.29$ & 16.30 & 77.07 & $27.55 \pm 14.08$ & 2.83 & 49.23 & $0.06 * *$ \\
\hline Vit. D $(\mu \mathrm{g})$ & $0.58 \pm 0.83$ & 0.00 & 2.67 & $0.96 \pm 1.26$ & 0.00 & 3.67 & $0.43 *$ \\
\hline
\end{tabular}

*man-whitney; **Independent t-test 
Semua subjek memiliki rentang usia 34 sampai 53 tahun. Subjek yang diteliti tidak mengkonsumsi obat-obatan selama intervensi berlangsung. Seluruh subjek yang diteliti juga tidak dalam keadaan sakit atau dalam perawatan dokter berkaitan dengan penyakit jantung koroner, diabetes mellitus, hipertensi, gagal ginjal, dan penyakit kronik lainnya. Seluruh subjek juga patuh terhadap intervensi yang diberikan selama penelitian. Sehingga didapatkan data distribusi kedua kelompok yang menunjukkan tidak ada perbedaan signifikan pada variabel usia, IMT, gula darah puasa, karbohidrat, protein, lemak, serat, vitamin A, vitamin $\mathrm{B} 1$, vitamin $\mathrm{B} 2$, vitamin $\mathrm{B} 6$, vitamin $\mathrm{C}$, dan vitamin D sebelum intervensi ( $p>0.05)$. Pada kelompok perlakuan maupun kelompok kontrol memiliki asupan zat gizi yang tergolong kurang, kecuali pada variabel vitamin A rerata asupan vitamin A dari keseluruhan subjek dapat dikatakan cukup.

Perbedaan Gula Darah Puasa Sebelum dengan Setelah Intervensi Antar Kelompok

Hasil analisis uji beda terhadap gula darah puasa sebelum, dan setelah intervensi antar kedua kelompok disajikan pada tabel 2 .

Tabel 3. Hasil uji beda gula darah puasa pre dan post intervensi antar dua kelompok

\begin{tabular}{|c|c|c|c|c|c|c|}
\hline \multirow{2}{*}{ Kelompok } & \multicolumn{3}{|c|}{ Perlakuan } & \multicolumn{3}{|c|}{ Kontrol } \\
\hline & Rerata \pm SD & Min & Max & Rerata \pm SD & Min & Max \\
\hline GDP sebelum intervensi (mg/dl) & $99.45 \pm 10.80$ & 84 & 117 & $95.64 \pm 13.50$ & 82 & 131 \\
\hline GDP setelah intervensi (mg/dl) & $89.64 \pm 9.45$ & 80 & 112 & $98.54 \pm 15.00$ & 88 & 141 \\
\hline$p^{*}$ & \multicolumn{3}{|c|}{0.001} & \multicolumn{3}{|c|}{0.176} \\
\hline
\end{tabular}

*Paired $t$-test

Tabel 4. Hasil uji beda gula darah puasa pada kelompok perlakuan dan kontrol

\begin{tabular}{|c|c|c|c|c|c|c|c|}
\hline \multirow{2}{*}{ Kelompok } & \multicolumn{3}{|c|}{ Perlakuan } & \multicolumn{3}{|c|}{ Kontrol } & \multirow{2}{*}{$p^{*}$} \\
\hline & Rerata \pm SD & Min & Max & Rerata \pm SD & Min & Max & \\
\hline GDP sebelum intervensi & $99.45 \pm 10.80$ & 84 & 117 & $95.64 \pm 13.50$ & 82 & 131 & $0.472^{*}$ \\
\hline GDP setelah intervensi & $89.64 \pm 9.45$ & 80 & 112 & $98.54 \pm 15.00$ & 88 & 141 & $0.049 * *$ \\
\hline
\end{tabular}

*independent t-test; **mann-whitney

Berdasarkan analisis, terdapat perbedaan signifikan gula darah puasa sebelum dan sesudah intervensi $(\mathrm{p}<0.05)$ pada kelompok perlakuan, dimana nilai awal $99.45 \pm 10.80 \mathrm{mg} / \mathrm{dl}$ dan nilai akhir sebesar $89.64 \pm 9.45 \mathrm{mg} / \mathrm{dl}$. Peningkatan kadar glukosa darah puasa terjadi pada kelompok kontrol, dari $95.64 \pm 13.50 \mathrm{mg} / \mathrm{dl}$ menjadi $98.54 \pm 15.00$ $\mathrm{mg} / \mathrm{dl}$. Kadar gula darah puasa tidak berbeda signifikan antara kelompok perlakuan dan kontrol sebelum intervensi dimana $\mathrm{p}=0.472 \quad(\mathrm{p}>0.05)$. Sedangkan kadar gula darah puasa setelah intervensi berbeda signifikan antara kelompok perlakuan dan kontrol dimana $\mathrm{p}=0.049(\mathrm{p}<0.05)$. Penurunan kadar gula darah puasa pada kelompok perlakuan lebih tinggi dibanding kelompok kontrol.

Hubungan asupan zat gizi dan aktivitas fisik terhadap kadar gula darah puasa pada kedua kelompok

Hasil analisis uji hubungan antara asupan zat gizi terhadap kadar gula darah puasa setelah intervensi disajikan pada tabel 5 .

Tabel 5. Hasil uji hubungan asupan zat gizi dan aktivitas fisik terhadap kadar gula darah puasa selama intervensi

\begin{tabular}{|c|c|c|c|c|}
\hline \multirow{2}{*}{ Variabel } & \multicolumn{4}{|c|}{ Gula Darah Puasa setelah } \\
\hline & Mean \pm SD & Min & Max & $\boldsymbol{P}$ \\
\hline Karbohidrat & $128.05 \pm 40.7$ & 62.93 & 223.67 & $0.82 * *$ \\
\hline Protein & $30.41 \pm 15.2$ & 15.00 & 68.33 & $0.85^{*}$ \\
\hline Lemak & $28.33 \pm 12.8$ & 13.67 & 62.17 & $0.21 *$ \\
\hline Serat & $6.00 \pm 2.78$ & 2.33 & 15 & $0.49 *$ \\
\hline Vit. A & $623.32 \pm 293.34$ & 214.67 & 1330.87 & $0.34 * *$ \\
\hline Vit. B1 & $0.32 \pm 0.14$ & 0.13 & 0.80 & $0.93^{*}$ \\
\hline Vit. B2 & $0.36 \pm 0.18$ & 0.13 & 0.93 & $0.72 *$ \\
\hline Vit. B6 & $0.64 \pm 0.30$ & 0.30 & 1.70 & $0.45^{*}$ \\
\hline Vit. C & $35.04 \pm 18.68$ & 2.83 & 77.07 & $0.99 * *$ \\
\hline Vit. D & $0.77 \pm 1.06$ & 0.00 & 3.67 & $0.06^{*}$ \\
\hline Aktivitas Fisik & $4.53 \pm 0.46$ & 3.82 & 5.55 & $0.49 * *$ \\
\hline
\end{tabular}

*spearman; **Person 
Berdasarkan analisis, tidak terdapat hubungan signifikan antara asupan zat gizi maupun aktivitas fisik terhadap kadar gula darah puasa setelah intervensi yaitu dengan masing-masing nilai ( $>0.05)$. Pada variabel lemak dan vitamin D memiliki masing-masing nilai $(p=0.21)$ dan $(p=0.06)$ yang artinya perlu dilakukan uji lanjutan dengan menggunakan uji multivariat untuk mengetahui pengaruhnya terhadap kadar gula darah puasa. Berdasarkan analisis multivariat antara vitamin D terhadap kadar gula darah puasa setelah intervensi memiliki nilai $(p=0.001)$ sehingga dapat disimpulkan terdapat hubungan antara vitamin D terhadap kadar gula darah puasa.

\section{PEMBAHASAN}

Subjek pada penelitian ini yaitu wanita dewasa dengan usia 34 - 53 tahun. Rata - rata IMT subjek penelitian yaitu $26.92 \pm 4.10$ dengan $59.09 \%$ subjek masuk ke dalam kategori obesitas. Hal ini dipengaruhi oleh kesibukan subjek yang sebagian besar memiliki pekerjaan dari pagi hingga sore sehingga menyebabkan ketidakteraturan pola makan. Sebagian besar subjek memiliki kadar gula darah puasa dengan rerata $(99.45 \pm 10.80)$ dan sebanyak $(72.73 \%)$ masuk kategori normal. Seluruh subjek penelitian memiliki asupan zat gizi yang rendah seperti KH (100\%), protein (86.37), lemak (86.37), serat $(100 \%)$, vitamin B1 $(100 \%)$, vitamin B2 (100\%), vitamin B6 (90.91\%), dan vitamin D (100\%). Sedangkan asupan vitamin A sebagian besar subjek masuk dalam kategori cukup (81.82\%). Hal ini disebabkan karena kurangnya kontrol asupan makanan seluruh subjek pada waktu, jenis, dan jumlah makanan. Terdapat beberapa subjek yang mengalami mual setelah mengkonsumsi rebusan daun binahong namun tidak sampai dilakukan perawatan. Hal ini disebabkan karena aroma dari rebusan daun binahong yang kurang bisa diterima oleh sebagian orang sehingga intervensi ini tidak dianjurkan pada ibu hamil. Pemberian intervensi dilakukan satu hari sekali diluar jam makan selama 14 hari. Intervensi yang diberikan dalam bentuk rebusan dengan tujuan untuk mengurangi rasa pahit pada daun binahong dan direbus selama \pm 4 menit dengan tujuan agar kandungan saponin tidak rusak. Berdasarkan struktur aglikonnya saponin terbagi 2 yaitu triterpenoid dan steroid. Triterpenoid merupakan senyawa yang larut dalam air sedangkan steroid larut dalam lemak.

Pengaruh rebusan daun binahong terhadap kadar gula darah puasa

Hasil penelitian ini membuktikan bahwa kadar gula darah puasa pada kelompok perlakuan mengalami penurunan signifikan setelah diberikan rebusan daun binahong sebanyak $155 \mathrm{~g} / \mathrm{kgBB}$.
Penurunan kadar gula darah puasa sebanyak $-9.82 \pm$ $5.78 \mathrm{mg} / \mathrm{dl}$. Sebaliknya peningkatan kadar gula darah puasa terjadi pada kelompok kontrol namun ada beberapa sampel yang mengalami penurunan dikarenakan adanya edukasi pada saat intervensi sehingga sampel membatasi asupan kalori. Peningkatan kadar gula darah dapat disebabkan karena ketidak seimbangan antara aktifitas fisik terdadap asupan makanan sehari-hari. Tidak ada perbedaan siginifikan kadar gula darah puasa antar kedua kelompok sebelum intervensi $(p=0.472)$ dan terdapat perbedaan signifikan setelah intervensi $(p=0.049)$.

Penurunan kadar gula darah puasa berhubungan dengan komponen aktif senyawa saponin dari daun binahong. Saponin memiliki aktivitas seperti insulin, dapat menghambat lipolisis, dan meningkatkan pengambilan glukosa oleh sel adipose. Sesuai dengan penelitian Indri Wirasuasty Makalalag.dkk menemukan bahwa konsumsi 1.8 $\mathrm{g} / \mathrm{kgBB}$ ekstrak daun binahong dan juga pengujian waktu penelitian selama 14 hari pada penelitian Elin Yulinah Sukandar.dkk dapat menurunkan kadar gula darah puasa. Mekanisme kerja insulin juga dapat menghambat aktifitas enzim alfa glukosidase (enzim yang bertanggung jawab pada pengubahan karbohidrat menjadi glukosa).

Bentuk intervensi pada penelitian ini menggunakan daun binahong segar yang direbus dengan jumlah yang sudah disesuaikan berdasarkan berat badan dan diujikan pada subjek manusia. Berbeda dengan studi lainnya yang umumnya menggunakan dalam bentuk ekstrak dan dengan sampel tikus, seperti pada penelitian Indri Wirasuasty Makalalag.dkk bahwa pemberian ekstrak daun binahong selama 14 hari dapat menurunkan kadar gula darah pada tikus wistar. Penggunaan ekstrak daun binahong juga ditemukan pada penelitian Elin Yulinah Sukandar.dkk bahwa terjadi penurunan kadar gula darah pada mancit. Hal ini menunjukkan bahwa perbedaan bentuk intervensi kemungkinan sama-sama memberikan efek positif terhadap penurunan kadar gula darah, akibat senyawa saponin yang dapat menghambat aktifitas enzim alfa glukosidase, menghambat lipolisis, dan meningkatkan pengambilan glukosa oleh sel adipose.

Hubungan asupan zat gizi dan aktivitas fisik terhadap kadar gula darah puasa pada kedua kelompok

Dari analisis asupan zat gizi yang dikaitkan dengan kadar gula darah puasa membuktikan bahwa tidak ada hubungan yang signifikan antara karbohidrat terhadap kadar gula darah puasa $(p=0.82)$. Hal ini sependapat dengan penelitian Ucik Witasari, dkk yang menyatakan bahwa tidak adanya hubungan antara karbohidrat terhadap penegendalian 
kadar gula darah puasa. ${ }^{29}$ Hasil analisis lemak terhadap gula darah puasa yaitu $(p=0.21)$ artinya tidak adanya hubungan antara konsumsi lemak terhadap kadar gula darah puasa. Hal ini dikarenakan pembatasan atau pengaturan konsumsi lemak bukan untuk memperbaiki melainkan mencegah peningkatan kadar gula dalam darah. Konsumsi lemak yang berlebihan dapat mengakibatkan pembesaran sel $\mathrm{K}$ yang berdampak pada peningkatan lemak tubuh, peningkatan aksi jaringan adipose, dan pembesaran sel beta. Hal tersebut akan menyebabkan terjadinya resistensi insulin yang mengakibatkan intoleransi glukosa. ${ }^{30}$

Hasil analisis protein terhadap kadar gula darah puasa yaitu $(p=0.85)$ yang artinya tidak ada hubungan antara konsumsi protein terhadap kadar gula darah puasa. Penelitian linn, dkk menyatakan bahwa ada hubungan yang signifikan antara asupan protein terhadap sekresi insulin. ${ }^{31} \mathrm{Hal}$ ini disebabkan karena kurangnya asupan protein (13.6\%) dengan kategori cukup (tabel. 1), sehingga kurang berperan dalam penurunan dula darah puasa. Semakin tinggi asupan protein maka semakin tinggi sekresi insulinnya sehingga dapat menjaga kadar gula dalam darah. Protein memiliki beberapa peran dalam pengendalian kadar gula dalam darah diantaranya yaitu apabila protein diberikan bersama dengan glukosa maka insulin dapat menangkap glukosa dengan baik dan protein juga dapat merangsang peningkatan konsentrasi insulin. ${ }^{32}$

Diet tinggi serat dapat meningkatkan kesensitifan sel-sel terhadap insulin. Serat yang larut dalam air dapat memperlambat aliran glukosa sehingga kadar gula dalam darah lebih stabil. Berbeda halnya dengan karbohidrat, serat dapat memperlama rasa kenyang sehingga tidak mudah tergoda untuk makan lebih banyak. ${ }^{33}$ Akan tetapi, penelitian ini menunjukkan bahwa tidak ada hubungan signifikan antara serat terhadap gula darah puasa $(p=0.49)$. Kemungkinan hal ini terjadi karena kurangnya responden dalam mengkonsumsi serat. Data menunjukkan bahwa tidak ada responden yang masuk dalam kategori cukup (23.1 g) dalam konsumsi serat. $^{27}$

Vitamin A (retinoid) memiliki fungsi salah satunya yaitu dalam metabolisme fungsi sel $\beta$ pankreas. Sementara Retinol Binding Protein (RBP), protein pengangkut retinoid, memiliki efek penting terhadap sensitivitas insulin yang bertindak sebagai adipokine. ${ }^{34}$ Fungsi vitamin A pada DM tipe 2 yaitu memperbaiki resistensi insulin dengan cara memblok TNF- $\alpha$ dan meningkatkan fungsi Glut-4 transporter yang membawa glukosa darah masuk ke dalam sel sehingga jumlahnya dalam darah menjadi normal. ${ }^{35}$ Hasil analisis antara vitamin A terhadap kadar gula darah puasa pada penelitian ini tidak ada hubungan signifikan dengan nilai ( $p=0.34$ ). Data asupan vitamin A sebagian besar responden dikategorikan cukup (90.9\%). Hal ini dapat disebabkan karena tidak adanya keseimbangan antara asupan vitamin A dengan asupan protein sehingga peran vitamin A tidak maksimal terhadap pengendalian kadar gula dalam darah. Defisiensi vitamin A dapat disebabkan oleh beberapa faktor diantaranya defisiensi protein dan $\mathrm{Zn}$, gangguan penyerapan dalam usus halus serta gangguan dalam proses konversi pro vitamin $\mathrm{A}$ menjadi vitamin $\mathrm{A}^{36}$

Hasil analisis antara vitamin B1, B2, dan B6 terhadap kadar gula dalam darah memiliki nilai masing-masing yaitu $(p=0.93), \quad(p=0.72), \quad$ dan $(p=0.45)$ yang berarti bahwa tidak adanya hubungan signifikan terhadap kadar gula dalam darah. Hal ini dikarenakan fungsi vitamin B bukan merupakan peran utama dalam pengendalian gula darah puasa. ${ }^{37}$ Adapun hasil analisis dari vitamin $\mathrm{C}$ terhadap kadar gula dalam darah yaitu $(p=0.99)$ yang dapat diartikan tidak adanya hubungan yang signifikan antara konsumsi vitamin $\mathrm{C}$ terhadap gula darah puasa. Penelitian ini berlawanan dengan penelitian Wulandari, dkk yang menyatakan bahwa terdapat hubungan yang signifikan antara vitamin $C$ terhadap kadar gula dalam darah. Fungsi dari vitamin C terhadap kadar gula dalam darah yaitu vitamin $\mathrm{C}$ dapat meningkatkan sensitivitas insulin dan mengurangi toksisitas glukosa, berkontribusi dalam pencegahan penurunan massa sel $\beta$ dan jumlah insulin. Vitamin $C$ juga berperan dalam memodulasi aksi insulin pada penderita DM, terutama dalam metabolisme glukosa non oksidatif. Dari tabel data karakteristik dapat dilihat asupan vitamin $\mathrm{C}$ sebagian besar responden dikategorikan kurang (86.4\%) sehingga peran vitamin $\mathrm{C}$ dalam pengendalian gula darah tidak maksimal.

Hasil analisis antara vitamin D terhadap kadar glukosa yaitu $(p=0.01)$ yang berarti adanya hubungan yang signifikan antara asupan vitamin D terhadap kadar gula dalam darah. Pada penelitian pittas AG, dkk menyatakan bahwa terdapat hubungan antara asupan vitamin D dari makanan terhadap DM2. Hal ini terjadi karena vitamin $\mathrm{D}$ berperan dalam regulasi fungsi sel $\beta$ terbukti oleh penemuan reseptor vitamin D pada sel $\beta$ dan gangguan kapasitas sekresi insulin pada tikus yang kekurangan reseptor vitamin D fungsional. ${ }^{38}$

Berkaitan dengan aktivitas fisik, penelitian di Denpasar menunjukkan hasil bahwa terdapat hubungan yang signifikan antara aktivitas fisik terhadap kadar gula darah. ${ }^{39}$ Dikarenakan latihan fisik secara teratur pada penderita diabetes dapat memperbaiki sensitivitas insulin. ${ }^{40}$ Selain itu penyerapan glukosa untuk pembentukan otot lebih baik dibanding lemak. Pembentukan otot dapat 
dilakukan dengan aktivitas fisik. ${ }^{41}$ Berbeda dengan penelitian ini, analisis hubungan antara aktivitas fisik terhadap kadar gula darah memiliki nilai $(p=0.29)$ yang artinya bahwa tidak terdapat hubungan yang signifikan. Hal ini dikarenakan kurangnya aktivitas fisik responden dengan seluruh responden memiliki kategori rendah.

\section{KETERBATASAN PENELITIAN}

Keterbatasan penelitian ini adalah tidak adanya kontrol asupan zat gizi terhadap subjek pada masing-masing kelompok sehingga dapat menjadi variabel perancu pada penelitian ini. Rebusan daun binahong yang diberikan tidak hanya mengandung senyawa saponin, namun juga terdapat beberapa senyawa lainnya sepertri alkaloids, polyphenols, flavonoid dan mono polysaccharide yang kemungkinan dapat berkontribusi terhadap hasil penelitian. Selain itu, pengujian dosis senyawa saponin belum dilakukan. Pengujian dosis diperlukan agar intervensi yang diberikan tepat dan lebih homogen.

\section{SIMPULAN DAN SARAN}

Penurunan kadar gula darah puasa pada kelompok perlakuan lebih tinggi dibandingkan kelompok kontrol setelah diberikan rebusan daun binahong sebanyak $155 \mathrm{~g} / \mathrm{kgBB}$ selama 14 hari. Perlu adanya penelitian lebih lanjut terhadap produkproduk yang dapat dihasilkan dengan menggunakan daun binahong seperti teh atau jeli dengan menggunakan daun binahong serta mempertimbangkan zat-zat lainnya yang terkandung dalam daun bianahong seperti alkaloids, polyphenols, flavonoid dan mono polysaccharide. Selain itu diperlukan pengujian dosis senyawa saponin pada daun binahong yang diberikan, agar intervensi yang diberikan lebih tepat dan lebih homogen.

\section{UCAPAN TERIMAKASIH}

Puji syukur kepada Allah SWT atas rahmat dan ijinnya penelitian ini dapat dilaksanakan. Terimakasih penulis ucapkan pada ibu-ibu di perumahan PGRI, kantor disnakertrans dan kantor kesbangpol kota semarang, yang telah bersedia menjadi subjek dan berpartisipasi dalam penelitian ini, serta tidak lupa dosen pembimbing dan penguji yang telah memberikan saran agar penelitian ini dapat dilakukan dengan baik. Tidak lupa terimakasih untuk para enumerator yang telah membantu dalam pengambilan data untuk penelitian.

\section{DAFTAR PUSTAKA}

1. Craig ME, Hattersley A, Donaghue KC. Definition, epidemiology and classification of diabetes in children and adolescents. Pediatric Diabetes 2009: 10 (Suppl. 12): 3-12.

2. Mehra N K, Kumar Neeraj, Kaur Gurvinder, Kanga Uma, Tandon Nikhil 2007. Biomarkers of susceptibility to type 1 diabetes with special reference to the Indian population. Indian J Med Res, 125: 321-344.

3. American Diabetes Association. Diagnosis and classification of diabetes mellitus. Diabetes Care 2012;35(Suppl. 1): dc12-s064.

4. World Health Organization (WHO). Diabetes (diakses 18 November 2012).

5. Dep. Kesehatan. DM Penyebab Kematian Nomor 6 di Dunia. 2013.

6. Kementrian kesehatan RI. Riset kesehatan dasar 2013. Badan penelitian dan pengembangan kesehatan. 2013. Page 87-90.

7. Grundy SM, Benjamin IJ, Burke GL, et al. Diabetes and cardiovascular desease: a statement for healthcare professionals from the american heart association. Circulation. 1999;100-1146.

8. Manson JE, Spelberg A. Risk modification in the diabetic patient. In: manson JE, Ridker PM, Gaziano JM, Hennekens CH, eds. Prevention of myocardial infarction. New york, NY: Oxford University Press; 1996:241-273.

9. Sizer Fs, Whitney E. The Carbohydrates : Sugar, Strach, Glycogen And Fibre. Dalam : Nutrition Concept And Controversies $11^{\text {th }}$ edition. Toronto: Wadsworth; 2008. Hal 121-138.

10. Ahmad Rudianto, DKK Dr. Ari Sutjahjo, dr.,Sp.PD-KEMD Prof. Dr. H. Askandar Tjokroprawiro et al. Konsensus Pengelolaan Dan Pencegahan DM Tipe 2 Di Indonesia. 2006.

11. Hadisaputro S, Setyawan H. Epidemiologi dan Faktor-Faktor Risiko terjadinya Diabetes Melitus Tipe 2. Dalam: Diabetes Melitus Ditinjau dari Berbagai Aspek Penyakit Dalam. Semarang: Badan Penerbit UNDIP (PERKENI): 2007.

12. Guyton AC, Hall JE. Insulin, glukagon, dan diabetes melitus. Dalam : Buku ajar fisiologi kedokteran. edisi 11. Jakarta : EGC; 2007.p.1010-28.

13. Irawan, Dedi. Prevalensi dan Faktor Risiko Kejadian Diabetes Melitus Tipe 2 di Daerah Urban Indonesia (Analisa Data Sekunder Riskesdas 2007). Tesis Universitas Indonesia. 2010.

14. Gupta V, Suri P. Diabetes in Elderly Patients. JK Practitioner. 2002;91(4):258-9.

15. Whitney E, Rolfes SR, Pinna K. The carbohydrates: Sugars, starches and fibers. Dalam : Understanding normal and clinical nutrition $8^{\text {th }}$ edition. Belmont : Wadsworth; 2009.p.100-25. 
16. Dequan, L. Flora of China. Northwestern Institute of Botany, China. 2003.

17. Rachmawati S. Study Macroscopic, dan Skrining Fitokimia Daun Anredera cordifolia (Ten) Steenis. Airlangga University. Indonesia. 2008.

18. Sri Murni Astuti, Retno Andayani B.M, Awalludin Risch. Determination of Saponin Compound from Anredera cordifolia (Ten) Steenis Plant (Binahong) to Potential Treatment for Several Diseases. 2011. Vol.3 no.4.

19. Xin $\mathrm{Hu}$, Sha Wang, Jing $\mathrm{Xu}$, et al. Triterpenoid Saponins from Stauntonia chinensis Ameliorate Insulin Resistance via the AMP-Activated Protein Kinase and IR/IRS-1/PI3K/Akt Pathways in Insulin-Resistant HepG2 Cells. 2014. 15: 10446-10458.

20. De Silva, U.L.L., G.R. Roberts. Products From Tea Seeds - Extraction and Properties of Saponin. Tea Research Institute, Sri Lanka, Tea O. 1972.43 (3): 91-94.

21. Susiana Prasetyo S, A. Prima K, Felicia Yosephine. Pengaruh Rasio Biji Teh / Pelarut Air Dan Temperatur Pada Ekstraksi Saponin Biji Teh Secara Batch. 2011. Page 19.

22. Aisyah Tri Septiana, Ari Asnani, Nuniek Ina Ratnaningtyas.

Karakteristik Fisikokimia Minuman Sargassum Crassifolium - Daun kumis Kucing Pada Berbagai Suhu Dan Lama Pencelupan. 2014.

23. Elin Yulinah Sukandar, Atun Qowiyyah, Lady Larasari. Efek Ekstrak Metanol Daun Binahong (Anredera Cordifolia (Ten.) Steenis) Terhadap Gula Darah Pada Mencit Model DM. 2011. Vol. 1 No. 4.

24. Indri Wirasuasty Makalalag, Adeanne Wullur, dan Weny wiyono. Uji Ekstrak Daun Binahong ( Anredera cordifolia Steen.) Terhadap kadar Gula Darah Pada Tikus Putih Jantan Galur Wistar ( Rattus norvegicus) yang Diinduksi Sukrosa. 2013. Vol.2. No 1.

25. Baecke JA, Burema J, Frijters JE. A Short Questionnaire For The Measurement Of Habitual Physical Activity in Epidemiological Studies. Am J Clin Nutr 1982.

26. Badan Penelitian Dan Pengembangan Kesehatan Kementerian Kesehatan RI. Riset Kesehatan Dasar. 2013.

27. KEMENKES. Angka Kecukupan Gizi Indonesia. 2013
28. Gibson RS. 2005. Principle of Nutritional Assessment. Second edition. New York (US): Oxford University Press.

29. Ucik Witasari, dkk. Hubungan Tingkat Pengetahuan, Asupan Karbohidrat Dan Serat Dengan Pengendalian Kadar Glukosa Darah Pada Penderita Diabetes Melitus Tipe 2. 2009.

30. Morgan And M, Linda. The Enteroinsular Axis. In Emmanuel Opara (Ed), Nutrition And Diabetes: Pathophysiology And Management (p. 27-42). 2005.

31. Linn, dkk. Effect Of Long-Term Dietary Protein Intake On Glucose Metabolism In Humans. 2000.

32. Gannon, Marry C, dkk. An Increase in Dietary Protein Improves The Blood Glucose Response in Personse With Type 2 Diabetes. American Journal Of Clinicalnutrition, 78,734-41. 20013.

33. Metzger, B. E. American Medical Association Guide To Living With Diabetes: Preventing And Treating Type 2 Diabetes-Essential Information You And Your Family Need To Know. 2006.

34. Brun PJ, Yang KJ, Lee SA, Yuen JJ, and Blaner WS. Retinoids: Potent Regulators of Metabolism. Biofactors. 2013; 39(2):151-163.

35. Widiowati W. Potensi Antioksidan sebagai Antidiabetes. Jakarta: JKM. 2008.

36. Muchtadi D. Gizi Anti Penuaan Dini. Bandung: Alfabeta. 2009. p 25-26.

37. Wibowo, Samekto. Hubungan Neuropati Otonom Diabetika Dengan Defisiensi tiamin. Skripsi. Universitas Gadjah Mada. 1999.

38. Pittas AG, Hughes BD, Van Dam RM, et.al. Vitamin D and Calcium Intake in Relation to Type 2 Diabetes in Women. Diabetes Care. 2006 ; 29 (3) : 650-56.

39. Darmaja K. Faktor-faktor yang mempengaruhi Peningkatan Kadar Gula Darah pada Pasien Lansia dengan Diabetes Mellitus di Persatuan Werdatama Republik Indonesia Cabang Kota Denpasar. Jurnal Dunia Kesehatan. 4(2). Pp 6574.

40. Budhiarta, dkk. Konsensus pengelolaan dan pencegahan diabetes mellitus tipe 2 di Indonesia. PB PERKENI. 2006.

41. National Institute of Diabetes and Digestive and Kidney Disease. Why I need to know about physical activity ang diabetes. 2014. 